Fakultas Hukum Universitas Lancang Kuning, Jalan Yos Sudarso KM 8 Rumbai Pekanbaru, Riau, Kode Pos 28266. Telp: (+62761)-51877

E-mail: jurnal.respublica@ac.id

Website: https://journal.unilak.ac.id/index.php/Respublica

\title{
Upaya Hukum Terhadap Suspend Dalam Perjanjian Kemitraan Antara PT. Gojek Indonesia dengan Driver
}

\author{
Mahlil Adriaman \\ ${ }^{a}$ Fakultas Hukum, Universitas Muhammadiyah Sumatera Barat, Indonesia, Email: mahliladriaman@gmail.com
}

\section{Article Info}

Article History:

Diterima : 11-12-2020

Direvisi : : 15-04-2021

Disetujui : 10-02-2021

Diterbitkan : 28-05-2021

\section{Keywords:}

Keyword 1 : Legal Efforts;

Keyword 2 : Suspend;

Keyword 3 : Agreement.

\begin{abstract}
Determination of violations made by Gojek Drivers in the city of Padang led to Suspend being issued by PT. Gojek Indonesia in the city of Padang. Suspen is a form of sanction for a violation by deactivating an account of a driver who has committed a violation so that it cannot be used to work again temporarily or permanently. There was a default of one of the parties in the implementation of the partnership agreement between PT. Gojek Indonesia with drivers, the solution can be done in two ways, namely by litigation and non-litigation. This is regulated in the Partnership Cooperation Agreement Article 5 Paragraph 1 regarding Dispute Resolution. Based on this article, there are two ways to be taken in dispute resolution, namely through deliberation and court.
\end{abstract}

\section{Informasi Artikel}

\section{Histori Artikel:}

Diterima : 11-12-2020

Direvisi : : 15-04-2021

Disetujui : 10-02-2021

Diterbitkan : 28-05-2021

\section{Kata Kunci:}

Kata Kunci 1 : Upaya Hukum;

Kata Kunci 2 : Suspen;

Kata Kunci 3 : Perjanjian.

\begin{abstract}
Abstrak
Penetapan pelangaran yang dilakukan oleh driver Gojek menyebabkan suspend yang di keluarkan oleh PT. Gojek Indonesia. Suspend merupakan bentuk sanksi atas suatu pelanggaran dengan menonaktifkan suatu akun driver yang telah melakukan pelanggaran sehingga tidak dapat digunakan lagi baik untuk sementara maupun permanen. Terjadi wanprestasi salah satu pihak dalam pelaksanaan perjanjian kerjasama kemitraan antara PT. Gojek Indonesia dengan driver, maka penyelesaiannya dapat dilakukan dengan dua cara yaitu secara litigasi dan non litigasi. Hal tersebut diatur dalam Perjanjian Kerjasama Kemitraan Pasal 5 Ayat 1 mengenai Penyelesaian Sengketa. Berdasarkan pasal tersebut, ada dua cara yang ditempuh dalam penyelesaian sengketa, yaitu melalui musyawarah dan pengadilan.
\end{abstract}

\section{PENDAHULUAN}

Perkembangan teknologi informasi ditengah - tengah masyarakat telah banyak menstransformasikan berbagai macam kegiatan sehari-hari dengan bantuan fitur aplikasi mobile yang tersedia pada alat komunikasi mereka. Salah satunya adalah dalam penggunaan alat transportasi yang sering digunakan masyarakat yang disebut dengan ojek. Kini ojek dijadikan salah satu tranportasi online dalam bentuk apliasi yang banyak digunakan oleh 
masyarkat. Ojek online sendiri dikenalkan ke tengah-tengah masyarkat dalam bentuk aplikasi oleh Nadiem Makariem pada awal 2015 dengan wilayah cakupan Jakarta, Bandung, Surabaya dan Bali yang diberi nama Go-Jek. Sampai saat ini armada yang dimiliki berjumlah ribuan. Fenomena kehadiran Go-Jek ditengah masyarakat cukup dirasakan pada masyarakat seluruh Indonesia. Ditengah kesibukan serta kemacetan yang kerap terjadi di kota-kota besar di Indonesia, Go-Jek menjadi pilihan menggunakan kendaraan motor yang lebih cepat dan mudah menjangkau kemacetan serta dapat menempuh jalan-jalan kecil, Go-Jek menjadi penolong terutama bagi para pemburu waktu. Layanan transportasi umum berbasis aplikasi mobile tentu sangat efektif dalam membantu melakukan masyarakat terutama dalam melakukan mobilitas.

PT. Gojek Indonesia adalah salah satu penyedia jasa ojek online. Perusahan ini didirikan oleh Nadiem Makarim pada tahun 2010 di Jakarta. Awalnya perusahan ini memberikan layanan transportasi roda dua melalui telepon dan mengalami berbagai pengembangan hingga menggunakan aplikasi smartphone. Untuk menarik pelanggan dari PT.GI sendiri tidak hanya menawarkan layanan pada bidang transportasi saja, selain itu ada layanan logistik, pembayaran, antar makanan, dan layanan pengantaran barang.

Struktur organisasi dari PT. Gojek Indonesia terbagi menjadi dua yaitu struktur organisasi pusat dan regional. Pada organisasi pusat berisi direktur utama yang terdiri dari chief executive, chief branding, chief product. Pada struktur regional terdiri dari Direktur utama, wakil direktur, manajer IT, manajer karyawan, manajer keuangan, manajer driver, karyawan. Karyawan pada perusahaan ini terdiri dari bidang programing, front office, dan driver. Driver gojek merupakan mitra PT. Gojek Indonesia dalam hal ini dilakukan pengikatan perjanjian kemitraan dengan ketentuan dan syarat yang harus di penuhi oleh driver gojek.

Perjanjian adalah suatu perhubungan hukum antara dua orang atau lebih, berdasarkan mana pihak yang satu berhak menuntut sesuatu dari pihak lain, dan pihak yang lain tersebut berkewajiban untuk memenuhi tuntutan itu. ${ }^{1}$ Perjanjian yang dilakukan pada PT. Gojek Indonesia dengan drivernya adalah dalam bentuk perjanjian kerjamasa kemitraan secara elektronok (e-contract).

Driver yang berhadapan langsung dengan pelanggan. Tugas dari driver adalah menyelesaikan pesanan sesuai dengan aturan yang diberikan manajer driver dan menjaga

\footnotetext{
${ }^{1}$ Subekti, R. "Pokok-Pokok Hukum Perdata”. (Jakarta: Intermasa, 1984). Hal. 1.
} 
hubungan baik dengan pelanggan, yaitu go-ride, go-food, go-mart, go-shop, go-med, dan gosend. Tugas driver mendapatkan penilain dari pelanggan setiap kali tugas diselesaikan dengan rating berupa bintang sejumlah 1 sampai 5. Jumlah bintang yang diberikan menunjukan bagaimana pelayanan driver terhadap pelanggan. Bintang 1 menujukan pelayanan yang sangat buruk, bintang 2 pelayanan buruk, bintang 3 pelayanan cukup, bintang 4 memuaskan, dan bintang 5 sangat memuaskan.

Penilaian dan komentar dari pelanggan atau penumpang inilah yang menjadi tolak ukur dari pihak PT. Gojek Indonesia untuk memutuskan driver gojek bersalah dan di berikan sangsi Suspend di mana aplikasi Driver gojek tidak bias di gunakan dalam waktu yang telah di tentukan atau tidak bisa digunakan selamanya atau di sebut juga istilah putus mitra.

Dari permasalahan di atas maka penulis tertarik untuk mengangkat ini menjadi penelitian untuk mengetahui bagaimana penyelesaian hukum atas suspen yang di berikan manajemen PT. Gojek Indonesia kepada driver di lihat dari perjanjian kemitraan.

\section{ANALISIS DAN PEMBAHASAN}

\section{Upaya Hukum Terhadap Suspend Dalam Perjanjian Kemitraan Antara PT. Gojek Indonesia dengan Driver}

Kemitraan adalah kerjasama dam keterkaitan usaha, baik langsung maupun tidak langsung, atas dasar rinsip saling memerlukan, mempercaya, memperkuat, dan mengntungkan yang melibatkan pelaku usaha mikro, kecil, dan menengah dengan usaha besar. ${ }^{2}$ Kemitraan secara aspek hukum ialah "A voluntary contract between two or more competent persons to place their money, effects, labor, and skill, or some or all of them, in lawful commerce or busniess, with the understanding thatthere shall be a prpotanional sharing of the profits and losse between them."3

Hubungan antara driver dengan PT. Gojek Indonesia mempunyai hubungan kemitraan. Adanya hubungan kemitraan tersebut, tentunya menghasilkan suatu perjanjian yang mengikat antara driver dengan perusahaan. Suatu perjanjian adalah suatu peristiwa di mana seorang berjanji pada seorang lain atau dua orang itu saling berjanji untuk melaksanakan sesuatu hal. ${ }^{4}$ Perjanjian menurut J. Satrio adalah perbuatan hukum dengan

\footnotetext{
${ }^{2}$ Undang-Undang Nomor 20 Tahun 2008 Tentang Usaha Mikro, Kecil, Menengah.

${ }^{3}$ Black's Law Dictionary, What is Partnership, http://thelawdictionary.org/partnership/, diakses pada tanggal 15 Juni 2021.

${ }^{4}$ I Ketut Oka Setiawan, Hukum Perikatan, (Jakarta: Sinar Grafika, 2016), 42.
} 
mana satu orang atau lebih mengikatkan dirinya terhadap satu orang lain atau lebih atau dimana satu oran lain atau lebih saling mengikatkan dirinya. ${ }^{5}$

Perjanjian yang dilakukan oleh pihak PT. Gojek Indonesia terhadap driver harus sesuai dengan syarat-syarat sah perjanjian yang telah tercantum dalam Pasal 1320 Kitab Undang-Undang Hukum Perdata (KUHPer) menentukan adanya 4 (empat) syarat sahnya suatu perjanjian, yakni:

1. Adanya kata sepakat bagi mereka yang mengikatkan dirinya;

2. Kecakapan para pihak untuk membuat suatu perikatan;

3. Suatu hal tertentu; dan

4. Suatu sebab (causa) yang halal. ${ }^{6}$

Syarat kata sepakat dan kecakapan para pihak disebut sebagai syarat subjektif karena menyangkut orang-orang yang membuat perjanjian tersebut, sementara dua syarat yang terakhir dinamakan syarat objektif karena mengenai perjanjiannya sendiri. ${ }^{7}$

Perjanjian yang dilakukan oleh PT. Gojek Indonesia dengan driver merupakan perjanjia kemitraan. Perjanjian kemitraan antara kedua belah pihak di lihat dari syarat sahnya perjanjian telah terpenuhi, tetapi isi perjanjian yang mencantumkan hak dan kewajiban para pihak terdapat saling tidak menguntungkan di kemudian hari oleh pihak driver yang mana salah satunya keputusan suspend atau sangsi yang di terima oleh pihak driver.

Solusi atas ketidakpastian yang ditawarkan kepada pengguna melalui sebuah perjanjian kemitraan, pada akhirnya keberadaan perjanjian juga yang melahirkan permasalahan baru. Dalam teori masyarakat, resiko ini yang disebut Beck sebagai efek bumerang. Kemitraan ini juga memberikan resiko ketidakpastian bagi para pengemudi atau driver, diantaranya orderan fiktif, dan ratting pelanggan. ${ }^{8}$

Apabila terjadi wanprestasi salah satu pihak dalam pelaksanaan perjanjian kerjasama kemitraan antara PT. Gojek Indonesia dengan driver, maka penyelesaiannya dapat dilakukan dengan dua cara yaitu secara litigasi dan non litigasi. Hal tersebut diatur dalam Perjanjian Kerjasama Kemitraan Pasal 5 Ayat (5.1) mengenai Penyelesaian Sengketa. Berdasarkan pasal tersebut, ada dua cara yang ditempuh dalam penyelesaian sengketa, yaitu melalui musyawarah dan pengadilan.

\footnotetext{
${ }^{5}$ J. Satrio, Hukum Perjanjian, (Bandung: Citra Aditya Bakti, 1996), 12.

${ }^{6}$ Subekti, Tjitrosudibio, Kitab Undang-Undang Hukum Perdata, ( Jakarta: Pradnya Paramita, 2003), 330.

${ }^{7}$ Handri Raharjo, Hukum Perjanjian di Indonesia, Cet Ke-1, (Yogyakarta: Pustaka Yustisia, 2009, 69.

${ }^{8}$ Beck Ulrich, Risk Society: Towards a New Modernity, (London: Sage Publication,1992).
} 
Mediasi pada pengadilan memperkuat upaya damai sebagaimana yang tertuang dalam hukum acara pasal 130 HIR (Het Herziene Indonesische Reglement) atau pasal 154 Rbg (Rechtreglement Buiten Gewesten). ${ }^{9}$ Hal ini ditegaskan dalam pasal 2 PERMA No. 1 Tahun 2008, yaitu semua perkara perdata yang diajukan di pengadilan tingkat pertama wajib untuk mengikuti mediasi, dan merupakan pelanggaran yang mengakibatkan putusan batal demi hukum apabila tidak menempuh prosedur mediasi. ${ }^{10}$

GO-JEK memilih penyelesaian sengketa melalui Pengadilan. Hal ini diatur dalam perjanjian kerjasama kemitraan Pasal 5 Ayat (5.1) mengenai Penyelesaian Sengketa. Perjanjian tersebut menyediakan perjanjian penyelesaian sengketa yang tidak realistis dan pasti tidak akan ada yang menempuhnya. Penyelesaian sengketa melalui Pengadilan sebenarnya hendak menyatakan bahwa penyedia jasa transportasi berbasis aplikasi tersebut tidak melayani tuntutan hukum yang diajukan oleh driver. Dan juga mengunakan mediasi atau musyawarah di luar pengadilan dengan cara peninjauan kembali pelangaran yang di lakukan oleh driver ojek online.

Pada dasarnya kontrak dibuat untuk saling menguntungkan dan bukan untuk saling merugikan atau untuk merugikan pihak lain. Oleh karena itu, walaupun undang-undang memungkinkan pihak yang dirugikan untuk membatalkan kontrak, selayaknya wanprestasiwanprestasi kecil atau tidak esensial tidak dijadikan alasan untuk pembatalan kontrak, melainkan hanya pemenuhan kontrak baik disertai tuntutan ganti rugi maupun tidak. ${ }^{11}$

Dengan demikian, walaupun pihak driver yang wanprestasi tidak dapat mengajukan salah satu pembelaan atau tangkisan, pihak PT. Gojek Indonesia tidak selamanya dapat menuntut pembatalan kontrak apabila prestasi yang dilakukan terlambat atau tidak sempurna. Salah satu tangkisan atau pembelaan yang dapat dilakukan oleh pihak driver yang dituduh wanprestasi dengan dalih orderan fiktif yaitu tidakdipenuhinya kontrak (wanprestasi) terjadi karena keadaan terpaksa (overmacht). Hal tersebut karena orderan secara otomatis masuk ke aplikasi driver. Selain itu, salah satu penyebab terjadinya orderan fiktif yaitu driver menyelesaikan orderan dari pelanggan yang sama secara berulang-ulang. Padahal orderan dari pelanggan yang sama tersebut masuk secara otomatis ke aplikasi driver dan driver juga tidak mengingat nama-nama pelanggan yang pernah dilayani oleh driver.

\footnotetext{
${ }^{9}$ Sarwono, Hukum Acara Perdata Teori dan Praktik, (Jakarta: Sinar Grafika,2011), 159.

${ }^{10}$ Mahkamah Agung RI, Peraturan Mahkamah Agung Republik Indonesia Nomor 1 Tahun 2008 Tentang Prosedur Mediasi di Pengadilan, bab I, pasal II.

${ }^{11}$ Ahmadi Miru, Hukum Perlindungan Konsumen, (Jakarta: Raja Grafindo Persada, 2013), 39.
} 
Kebanyakan driver harus menerima orderan yang masuk tersebut. Karena apabila ia tidak menerima orderan tersebut, dapat mengakibatkan performa di aplikasi driver menurun. Performa bertujuan untuk mengukurkinerja dari driver dalam melayani pelanggan, terutama dalam hal penerimaan order. Performa dihitung berdasarkan jumlah order yang masuk ke aplikasi driver. Jika driver tidak mengambil order yang masuk ke aplikasinya dan jika order di cancel (dari sisi customer/driver/call center) maka tingkat penyelesaian orderannya akan turun. Turunnya performa tersebut tentu sangat mempengaruhi apakah driver mendapat bonus harian atau tidak. Overmacht atau force majeure merupakan keadaan di mana seorang debitur terhalang untuk melaksanakan prestasinya karena keadaan atau peristiwa yang tidak terduga pada saat dibuatnya kontrak, keadaan atau peristiwa tersebut tidak dapat dipertanggungjawabkan kepada debitur, sementara si debitur tersebut tidak dalam keadaan beritikad buruk. $^{12}$

Dalam pelaksanaannya, apabila driver dianggap wanprestasi oleh pihak PT. Gojek Indonesia, biasanya pihak driver terkena sanksi berupa suspend (putus hubungan kemitraan) atau membayar ganti rugi sesuai dengan kesalahan yang dilakukan. Hal tersebut karena dianggap telah menimbulkan kerugian bagi perusahaan.

Berdasarkan dalam klausula perjanjian kemitraan PT. Gojek Indonesia tentang Keberlakuan Perjanjian disebutkan bahwa perjanjian akan berlaku selama 1 (satu) tahun sejak tanggal mitra mengklik persetujuan kemitraan secara elektronik. Apabila perjanjian ini tidak diakhiri maka sesuai dengan syarat dan ketentuan perjanjian, periode keberlakuan perjanjian akan diperpanjang secara otomatis setelah berakhirnya periode 1 (satu) tahun. Berakhirnya perjanjian kemitraan PT. Gojek Indonesia dapat dikarenakan apabila mitra melakukan tindakan kecurangan, seperti penggunaan aplikasi tambahan dan orderan fiktif. Isi perjanjian kemitraan mengenai berakhirnya perjanjian kemitraan ditegaskan dalam salah satu isi pasal bahwa : GO-JEK, AKAB, maupun Mitra berhak untuk mengakhiri perjanjian secara sepihak sewaktu - waktu sebelum berakhirnya masa berlaku perjanjian dengan mengesampingkan ketentuan pada Pasal 1266 Kitab Undang - Undang Hukum Perdata.

Apabila dilihat dalam Pasal 1266 Kitab Undang - Undang Hukum Perdata mengatur bahwa : Syarat batal dianggap selalu dicantumkan dalam persetujuan yang timbal balik, andaikata salah satu pihak tidak memenuhi kewajibannya. Dalam hal demikian persetujuan

\footnotetext{
${ }^{12}$ Munir Fuady, Hukum Kontrak Dari Sudut Pandang Hukum Bisnis, Cet. 2, (Bandung: Citra Aditya Bakti, 2001), 40.
} 
tidak batal demi hukum, tetapi pembatalan harus dimintakan kepada Pengadilan. Permintaan ini juga harus dilakukan, meskipun syarat batal mengenai tidak dipenuhinya kewajiban dinyatakan di dalam persetujuan. Jika syarat batal tidak dinyatakan dalam persetujuan, maka Hakim dengan melihat keadaan, atas permintaan tergugat, leluasa memberikan suatu jangka waktu untuk memenuhi kewajiban, tetapi jangka waktu itu tidak boleh lebih dan satu bulan.

Alasan dan pengertian mengenai dikesampingkannya pasal 1266 Kitab Undang Undang Hukum Perdata adalah agar pembatalan suatu perjanjian tidak perlu melalui proses permohonan batal ke pengadilan dapat hanya berdasarkan kesepakatan pihak itu sendiri. ${ }^{13}$ Dalam hal berakhirnya perjanjian kemitraan ini, pihak PT. Gojek Indonesia menegaskan paling lambat 3 (tiga) hari sejak berakhirnya perjanjian, mitra wajib melunasi setiap jumlah jumlah yang masih terhutang kepada pihak PT. Gojek Indonesia, AKAB, maupun pihak ketiga lainnya termasuk juga didalamnya uang penalti atas pelanggaran yang dilakukan oleh mitra. Begitu juga dengan pihak PT. Gojek Indonesia atau AKAB akan mengembalikan setiap surat - surat jaminan seperti barang atau dokumen lainnya yang telah diserahkan oleh mitra kepada PT. Gojek Indonesia atau AKAB pada waktu dilakukannya pendaftaran sebagai mitra PT. Gojek Indonesia maupun yang mungkin diminta oleh PT. Gojek Indonesia atau AKAB selama menjadi mitra PT. Gojek Indonesia.

Dengan berakhirnya perjanjian kemitraan PT. Gojek Indonesia, maka segala hak yang diberikan oleh $\mathrm{AKAB}$ kepada mitra juga ikut dinyatakan berakhir termasuk juga AKAB mempunyai kewenangan atau hak untuk menutup akses mitra atas akun yang dimilikinya dalam aplikasi PT. Gojek Indonesia

\section{KESIMPULAN}

Dalam perjanjian kemitraan antara driver dengan PT. Gojek Indonesia justru menghadirkan berbagai persoalan negatif yang harus dihadapi, Dimana dari kemitraan timbul kasus di mana pihak yang harus merasakan dampaknya adalah para pengemudi gojek selaku pihak yang menggunakan aplikasi gojek. Adapun beberapa faktor resiko yang dihadapi oleh pengemudi gojek, diantaranya: Orderan Fiktif. Orderan fiktif termasuk kedalam tindak penipuan yang secara tidak langsung akan merugikan salah satu pihak, dalam hal ini pengemudi gojek. Dampak dari suspen ini seperti penurunan performa pengemudi hingga berakibat PM (Putus Mitra) bagi pengemudi. Penyelesaian masalahnya lebih baik

\footnotetext{
${ }^{13}$ R. Subekti dan R. Tjitrosudibio, Kitab Undang- Undang Hukum Perdata, 2001, 328.
} 
mengunakan mediasi dengan meminta keterangan dari driver terkait masalah suspen yang di berikan pihak PT. Gojek Indonesia

\section{DAFTAR PUSTAKA}

Ahmadi Miru.2013. Hukum Perlindungan Konsumen. Jakarta: Raja Grafindo Persada.

Beck, Ulrich. 1992. Risk Society: Towards a New Modernity. London: Sage Publication

Black's Law Dictionary, What is Partnership, http://thelawdictionary.org/partnership/, diakses pada tanggal 15 Juni 2021.

Fuady, Munir. 2001. Hukum Kontrak Dari Sudut Pandang Hukum Bisnis. Cet. 2. Bandung: Citra Aditya Bakti.

Mahkamah Agung RI, Peraturan Mahkamah Agung Republik Indonesia Nomor 1 Tahun 2008 Tentang Prosedur Mediasi di Pengadilan, bab I, pasal II.

Munir Fuady. 2001. Hukum Kontrak Dari Sudut Pandang Hukum Bisnis. Cet. 2. Bandung: Citra Aditya Bakti.

Raharjo, Handri. 2009. Hukum Perjanjian di Indonesia. Yogyakarta: Pustaka Yustisia.

Sarwono. 2011. Hukum Acara Perdata Teori dan Praktik. Jakarta: Sinar Grafika.

Satrio, J. 1996. Hukum Perjanjian, Bandung: Citra Aditya Bakti.

Setiawan, I Ketut Oka. 2016. Hukum Perikatan. Jakarta: Sinar Grafika.

Subekti, R dan Tjitrosudibio, R. 2001. Kitab Undang- Undang Hukum Perdata.

Subekti, R. 1984. Pokok-Pokok Hukum Perdata. Jakarta: Intermasa

Subekti dan Tjitrosudibio. Kitab Undang-Undang Hukum Perdata. Jakarta: Pradnya Paramita 2003

Undang-Undang Nomor 20 Tahun 2008 Tentang Usaha Mikro, Kecil, Menengah. 